\title{
RNAi-mutants of Sorghum bicolor (L.) Moench with improved digestibility of kafirins
}

Elkonin L.A., Panin V.M., Kenzhegulov O.A., Sarsenova S.Kh.

Agricultural Research Institute of South-East Region, Saratov

$$
\text { E-mail: lelkonin@gmail.com }
$$

Key message. RNAi-mutant with improved kafirin digestibility was obtained in commercial cv. of grain sorghum Avans. In the cv. Zheltozernoe 10, functionally marker-free transgenic plants with improved kafirin digestibility were identified.

Keywords: Sorghum bicolor (L.) Moench, transgenic plants, Agrobacterium-mediated genetic transformation, gamma-kafirin, RNA silencing

Modification of the composition of grain storage proteins is an intensively developing area of plant biotechnology, which is of particular importance for sorghum - high-yielding drought tolerant crop. Compared with other cereals, the majority of sorghum cultivars and hybrids are characterized by reduced nutritional value that is caused by a low content of essential amino acids in the seed storage proteins (kafirins), and resistance of kafirins to protease digestion. Suppressing the synthesis of individual kafirin subclasses can be an effective approach to solve this problem, since it leads to a rebalancing of the kernel proteome, and to the synthesis of other proteins with a higher content of essential amino acids, and to the changes in the ultrastructure of protein bodies that become more sensitive to proteolytic digestion. Our studies are aimed at creating sorghum lines with a suppressed synthesis of $\gamma$-kafirin, the most resistant to protease digestion, which is located at a periphery of protein bodies and prevents the digestion of other kafirins. To solve this problem, we conducted experiments on the introduction of a genetic construct capable of RNA silencing of the $\gamma$-kafirin gene, into the genomes of the grain sorghum cultivars Zheltozernoye 10 and Avans through Agrobacterium-mediated genetic transformation. In these experiments, we used the A. tumefaciens strain GV3101/pNRKAF that contained in the T-DNA region the bar gene under the control of nospromoter and the genetic construct for RNA-silencing consisting of inverted fragments of the $\gamma$-kafirin gene separated by the ubiquitin-intron sequence [1]. Immature embryos were pre-cultured for 3 days, then they were inoculated with the agrobacterial suspension, which was grown, first, in YEP medium $\left(10 \mathrm{~h}, 28{ }^{\circ} \mathrm{C}, 200 \mathrm{rpm}\right)$, and then in $\mathrm{AB}$ medium with acetosyringone $\left(20\right.$ hours, $\left.23{ }^{\circ} \mathrm{C}, 60 \mathrm{rpm}\right)$. Co-cultivation (4 days, $23{ }^{\circ} \mathrm{C}$ ) was carried out on a filter paper moistened with M1 1 medium [1]. The same medium was used at the resting $\left(7\right.$ days, $\left.28{ }^{\circ} \mathrm{C}\right)$ and selection stages. In Avans variety, 19 plants $\left(\mathrm{T}_{0}\right.$ generation) were regenerated from transformed calli after two cycles of selection on the M11 medium with ammonium glufosinate (2.5 mg/l). In one plant, \#1-1, PCR analysis showed amplification of the target sequences of the nos-promoter and $u b i$-intron. The transformation frequency was $1.4 \%$, which corresponds to the literature data on application of GV3101 strain in experiments on Agrobacterium-mediated genetic transformation of sorghum. A PCR analysis of the $\mathrm{T}_{1}$ progeny obtained from this plant confirmed the inheritance of the introduced genetic construct. Analysis of digestibility of endosperm proteins by pepsin treatment followed by SDS-PAGE and digital processing the electrophoretic spectra showed a significantly higher digestibility of kafirins in the mutant compared to the original non-transgenic cultivar and non-transgenic regenerants $(93 \%$ against 57-62\%). Analysis of the endosperm texture of transgenic kernels showed the complete disappearance of the vitreous endosperm, which was to be expected in the case of expression of the introduced genetic construct. It is noteworthy that the vitreous endosperm in the kernels of Avans has a dark color, indicating the presence of tannins, which reduce the nutritional value of the grain. Thus, two factors - the removal of the vitreous endosperm containing tannins, and the improvement of the digestibility of kafirins - indicate a potentially higher nutritional value of the mutant grain, compared with the grain of the original variety Avans. In the cv. Zheltozernoe 10, an analysis of the digestibility of endosperm proteins in $\mathrm{T}_{4}$ and $\mathrm{T}_{5}$ progeny of transgenic plants, which we obtained earlier [1], showed that the introduced genetic construct continues to function, increasing the digestibility of kafirins, compared to the original non-transgenic line. Remarkably, PCR analysis with primers to the nos-promoter that governs the expression of the bar gene, showed its absence in majority of the studied plants, although amplification of the target sequence of $u b i$-intron was observed. Therefore, these transgenic plants with improved digestibility of kafirins are functionally marker-free. This finding would greatly facilitate their introduction into agricultural production. This work was partially supported by the Russian Foundation for Basic Research, grant No. 19-016-00117.

[1] Elkonin L.A., Italianskaya J.V., Domanina I.V. et al. Transgenic sorghum with improved digestibility of storage proteins obtained by Agrobacterium-mediated transformation // Russ. J. Plant Physiol., 2016, 63, p. 678-689. 